\title{
Size-Resolved Water-Soluble Ionic Composition of Ambient Particles in an Urban Area in Southern Poland
}

\author{
Wioletta Rogula-Kozlowska ${ }^{1}$, Izabela Sówka ${ }^{2}$, Barbara Mathews ${ }^{1}$, Krzysztof Klejnowski ${ }^{1}$, \\ Anna Zwoździak ${ }^{2}$, Kornelia Kwiecińska ${ }^{2}$
}

${ }^{1}$ Institute of Environmental Engineering, Polish Academy of Sciences, Zabrze, Poland; ${ }^{2}$ Ecologistics Division, Institute of Environmental Protection Engineering, Wroclaw University of Technology, Wroclaw, Poland.

Email: wioletta@ipis.zabrze.pl

Received February $10^{\text {th }}, 2013$; revised March $12^{\text {th }}, 2013$; accepted April $10^{\text {th }}, 2013$

Copyright (C) 2013 Wioletta Rogula-Kozłowska et al. This is an open access article distributed under the Creative Commons Attribution License, which permits unrestricted use, distribution, and reproduction in any medium, provided the original work is properly cited.

\begin{abstract}
The ambient concentrations of PM-related anions $\left(\mathrm{Cl}^{-}, \mathrm{NO}_{3}^{-}, \mathrm{SO}_{4}^{2-}\right)$ and cations $\left(\mathrm{Na}^{+}, \mathrm{NH}_{4}^{+}, \mathrm{K}^{+}, \mathrm{Ca}^{2+}, \mathrm{Mg}^{2+}\right)$, total and contained in the PM fractions, were investigated in a typical urban area within the Silesian Agglomeration. A DEKATI low pressure impactor (DLPI) was used to sample PM and separate it into 13 fractions. The PM concentrations were determined gravimetrically, the ion content of the PM water extracts-by means of ion chromatography (Herisau Metrohm AG ion chromatograph). In general, sulfate, nitrate, and ammonia had the greatest ambient concentrations. $\mathrm{PM}_{1}$ contained over $60 \%$ of the PM-related sulfate and nitrate mass and $90 \%$ of the ammonia mass. Also the majority of $\mathrm{Na}^{+}$and $\mathrm{Cl}^{-}$were bound onto fine particles. Instead, more of the PM-related $\mathrm{K}^{+}, \mathrm{Ca}^{2+}$ and $\mathrm{Mg}^{2+}$ mass were in $\mathrm{PM}_{2.5-10}$ than in $\mathrm{PM}_{2.5}$. In the fine particles (sub-fractions of $\mathrm{PM}_{1.6}$ ) sulfate, nitrate and ammonia occur mainly as $\left(\mathrm{NH}_{4}\right)_{2} \mathrm{SO}_{4}$ and $\mathrm{NH}_{4} \mathrm{NO}_{3}$. In the sub-fractions of $\mathrm{PM}_{1.6-10}$ sulfate and nitrate might also occur as $\mathrm{K}_{2} \mathrm{SO}_{4}, \mathrm{CaSO}_{4}, \mathrm{Ca}\left(\mathrm{NO}_{3}\right)_{2}$ or $\mathrm{NaNO}_{3}$.
\end{abstract}

Keywords: Ambient Aerosol; DEKATI; Mass Size Distribution; SIA; Ammonium Sulfate; Ammonium Nitrate; Neutralization Ratio; Upper Silesia

\section{Introduction}

To assess the impact of atmospheric aerosol on the environment, including air quality, ecosystems, human health and climate change, it is necessary to know its concentration, chemical composition and mass size distribution of PM (ambient particulate matter) components [1-8]. Knowledge of the mass size distribution of PM components is helpful in determining mechanisms of aerosol formation, as well as physical and chemical changes, it is subjected to on a given area [9-13].

Besides the obvious and relatively well-recognized relation between the content of various toxic compounds in ambient dust and human health [14-17], another example of a dust chemical composition impact on the environment, is the effect of some water-soluble inorganic compounds on the acidity and conductivity of aerosols. Under certain conditions, the water-soluble sulfur and nitrogen compounds contained in the dust, contribute to acidification of precipitation and/or deposition, whereas the deposition of particles rich in the water-soluble calcium, magnesium, potassium or sodium compounds, increases the alkalinity of the environment [18-21].

Water-soluble ions, next to elemental carbon and organic matter, dominate the mass of PM. In urban areas, mass of sulfates $\left(\mathrm{SO}_{4}^{2-}\right)$ and nitrates $\left(\mathrm{NO}_{3}^{-}\right)$associated with particulate matter is even $\sim 80 \%$ of all water extracted ions (Table 1, [22]) and $\sim 15 \%-50 \%$ of the total mass of $\mathrm{PM}_{2.5}$ (fine particles, with aerodynamic diameters not exceeding $2.5 \mu \mathrm{m}$ ) [23-26].

Sulfates, nitrates and ammonia are used to determine the share of secondary inorganic aerosol (SIA) in the mass of ambient dust. Oxidation of $\mathrm{SO}_{2}$ in the air, then a binary nucleation of $\mathrm{H}_{2} \mathrm{SO}_{4}-\mathrm{H}_{2} \mathrm{O}$ and ternary $\mathrm{H}_{2} \mathrm{SO}_{4-}$ $\mathrm{H}_{2} \mathrm{O}-\mathrm{NH}_{3}$, results in the formation of dust particles, mostly smaller than $1 \mu \mathrm{m}[19,21,27,28]$. These particles, together with nitrate $(\mathrm{V})$ ammonium emerging in the analogous reaction of nitric acid $(\mathrm{V})$ with ammonia, form 
Table 1. Ambient concentrations of water-soluble ions $\left(\mathrm{ng} \cdot \mathrm{m}^{-3}\right)$ related to various PM fractions at various sites in Europe.

\begin{tabular}{|c|c|c|c|c|c|c|c|c|c|c|}
\hline $\begin{array}{l}\text { City (Country); description of the } \\
\text { measuring point; [references] }\end{array}$ & $\begin{array}{l}\text { Averaging } \\
\text { period }\end{array}$ & Fraction & $\mathrm{Cl}^{-}$ & $\mathrm{NO}_{3}^{-}$ & $\mathrm{SO}_{4}^{2-}$ & $\mathrm{Na}^{+}$ & $\mathrm{NH}_{4}^{+}$ & $\mathrm{K}^{+}$ & $\mathrm{Ca}^{2+}$ & $\mathrm{Mg}^{2+}$ \\
\hline \multirow{2}{*}{$\begin{array}{l}\text { Bern (Switzerland); kerbside in the } \\
\text { city center; [33] }\end{array}$} & \multirow{2}{*}{ 04.1998-03.1999 } & $\mathrm{PM}_{2.5}$ & 102 & 3000 & 2800 & 94 & 1600 & 180 & 132 & 8.5 \\
\hline & & $\mathrm{PM}_{2.5-10}$ & 1012 & 1100 & 700 & 746 & 0 & 48 & 1420 & 37 \\
\hline \multirow{3}{*}{ Basel (Switzerland); suburban; [33] } & \multirow{2}{*}{ 04.1998-03.1999 } & $\mathrm{PM}_{2.5}$ & 145 & 3100 & 4100 & 111 & 2000 & 218 & 71 & 13 \\
\hline & & $\mathrm{PM}_{2.5-10}$ & 111 & 700 & 100 & 128 & 100 & 28 & 279 & 26 \\
\hline & \multirow{4}{*}{ Summer 1999} & $\mathrm{PM}_{0.11}$ & - & 1 & 48 & - & 40 & 46 & - & - \\
\hline \multirow{3}{*}{ K-puszta (Hungary); rural site; [34] } & & $\mathrm{PM}_{1.05}$ & - & 64 & 2590 & - & 1139 & 198 & - & - \\
\hline & & $\mathrm{PM}_{2.60}$ & - & 95 & 2655 & - & 1173 & 240 & - & - \\
\hline & & $\mathrm{PM}_{10.77}$ & - & 133 & 2667 & - & 1194 & 286 & - & - \\
\hline \multirow{2}{*}{$\begin{array}{l}\text { Bemantes (Spain); seaside } \\
\text { background; [35] }\end{array}$} & \multirow{2}{*}{ Whole year 2001} & $\mathrm{PM}_{10}$ & 1259 & 862 & - & - & 1329 & - & - & - \\
\hline & & $\mathrm{PM}_{2.5}$ & 555 & 399 & - & - & 1152 & - & - & - \\
\hline \multirow{2}{*}{$\begin{array}{l}\text { Barcelona (Spain); impact of } \\
\text { industry; [36] }\end{array}$} & \multirow{2}{*}{ Whole year 2001} & $\mathrm{PM}_{10}$ & - & 7200 & - & - & 3900 & - & - & - \\
\hline & & $\mathrm{PM}_{2.5}$ & - & 5200 & - & - & 3700 & - & - & - \\
\hline \multirow{2}{*}{$\begin{array}{l}\text { Tarragona (Spain); impact of } \\
\text { road traffic; [36] }\end{array}$} & \multirow{2}{*}{ Whole year 2001} & $\mathrm{PM}_{10}$ & - & 6000 & - & - & 2200 & - & - & - \\
\hline & & $\mathrm{PM}_{2.5}$ & - & 3800 & - & - & 1600 & - & - & - \\
\hline \multirow{2}{*}{$\begin{array}{l}\text { Helsinki (Finland); urban } \\
\text { background; [37] }\end{array}$} & \multirow{2}{*}{ 08.2002-09.2002 } & $\mathrm{PM}_{2.5}$ & 11.9 & 303 & 1850 & 61.6 & 791 & 47.1 & 24.1 & 9.35 \\
\hline & & $\mathrm{PM}_{2.5-10}$ & 124 & 445 & 146 & 122 & 20.8 & 15.4 & 191 & 27.8 \\
\hline \multirow{7}{*}{ Menen (Belgium); suburban; [38] } & Spring 2003 & $\mathrm{PM}_{2.5}$ & 260 & 8120 & 4760 & - & 2340 & 120 & 80 & 20 \\
\hline & Summer 2003 & $\mathrm{PM}_{2.5}$ & 250 & 4170 & 3230 & - & 1920 & 130 & 60 & 20 \\
\hline & Autumn 2003 & $\mathrm{PM}_{2.5}$ & 370 & 4100 & 3700 & - & 1740 & 210 & 50 & 30 \\
\hline & Winter 2003 & $\mathrm{PM}_{2.5}$ & 890 & 5280 & 4990 & - & 1880 & 250 & 70 & 30 \\
\hline & $1999 / 2000$ & $\mathrm{PM}_{10}$ & & & & - & - & - & - & - \\
\hline & $2000 / 2001$ & $\mathrm{PM}_{10}$ & & & & - & - & - & - & - \\
\hline & $2001 / 2002$ & $\mathrm{PM}_{10}$ & & & & - & - & - & - & - \\
\hline \multirow[t]{6}{*}{$\begin{array}{l}\text { Zagreb (Croatia); } \\
\text { residential-industrial-traffic site; [39] }\end{array}$} & $2002 / 2003$ & $\mathrm{PM}_{10}$ & & & & & & & & \\
\hline & $2003 / 2004$ & $\mathrm{PM}_{10}$ & & & & & & & & \\
\hline & $2004 / 2005$ & $\mathrm{PM}_{10}$ & & & & & & & & \\
\hline & $2006 / 2006$ & $\mathrm{PM}_{10}$ & & & & - & - & - & - & - \\
\hline & & $\mathrm{PM}_{10}$ & 160 & - & - & 300 & - & 120 & 140 & 50 \\
\hline & $\begin{array}{l}\text { Summer season } \\
(2004-2008)\end{array}$ & $\mathrm{PM}_{2.5}$ & 50 & - & - & 110 & - & 80 & 80 & 20 \\
\hline \multirow{4}{*}{$\begin{array}{l}\text { Melpitz (Germany); } \\
\text { rural background; [40] }\end{array}$} & & $\mathrm{PM}_{1}$ & 30 & - & - & 40 & - & 60 & 50 & 10 \\
\hline & & $\mathrm{PM}_{10}$ & 570 & - & - & 430 & - & 180 & 110 & 70 \\
\hline & $\begin{array}{l}\text { Winter season } \\
(2004-2008)\end{array}$ & $\mathrm{PM}_{2.5}$ & 240 & - & - & 160 & - & 140 & 70 & 30 \\
\hline & & $\mathrm{PM}_{1}$ & 120 & - & - & 40 & - & 100 & 50 & 10 \\
\hline \multirow{2}{*}{$\begin{array}{l}\text { near Chania (Crete, Greece); } \\
\text { urban background; [41] }\end{array}$} & 08.2007 & $\mathrm{PM}_{10}$ & 3295 & 4946 & 18,725 & 3397 & 720 & 668 & 511 & 136 \\
\hline & 07.2008 & $\mathrm{PM}_{10}$ & 2649 & 1620 & 6353 & 4432 & 1466 & 669 & 2459 & 314 \\
\hline \multirow{3}{*}{$\begin{array}{l}\text { Zabrze (Poland); urban } \\
\text { background; [this study] }\end{array}$} & \multirow{3}{*}{$08-12.2008$} & $\mathrm{PM}_{1}$ & 567 & 715 & 1284 & 157 & 775 & 163 & 146 & 36 \\
\hline & & $\mathrm{PM}_{2.5}$ & 684 & 880 & 1706 & 220 & 956 & 184 & 210 & 51 \\
\hline & & $\mathrm{PM}_{10}$ & 775 & 1046 & 1927 & 273 & 962 & 191 & 345 & 79 \\
\hline
\end{tabular}


the SIA. In the air poor in $\mathrm{NH}_{4}^{+}$, sulfuric acid $\mathrm{H}_{2} \mathrm{SO}_{4}$ can react with mineral dust or sea salt components, generally creating coarse particles of $\mathrm{CaSO}_{4}$ or $(\mathrm{Na})_{2} \mathrm{SO}_{4}$.

The goal of the work was to determine concentration and mass size distribution of eight water-soluble ions $\left(\mathrm{Cl}^{-}, \mathrm{NO}_{3}^{-}, \mathrm{SO}_{4}^{2-}, \mathrm{Na}^{+}, \mathrm{NH}_{4}^{+}, \mathrm{K}^{+}, \mathrm{Ca}^{2+}, \mathrm{Mg}^{2+}\right)$ related to thirteen PM fractions in a typical urban area of southern Poland. Possible chemical composition of secondary inorganic aerosol in 13 dust fractions was also estimated.

\section{Material and Methods}

The site of experiment (Zabrze, Poland, Figure 1) is located in area representative of the air pollution conditions for the central part of Upper Silesia and it meets the criteria of urban background site (Directive 2008/50/EC). Conditions at this point, characterize well dust concentration in residential areas exposed to municipal and industrial emissions in the Upper Silesia [29].

Samples have been collected from August to December 2008. Fourteen measurements were carried out and each lasted about a week. Dust was collected using a thirteen stage DEKATI low pressure impactor (DLPI) [13].

Masses of dust collected on aluminum substrates, were determined by weighing substrates before and after exposure, on a Mettler Toledo microbalance (accuracy 2 $\mu \mathrm{g}$ ). Before weighing the substrates were kept in weighing room for 48 hours (temperature $20^{\circ} \mathrm{C} \pm 2^{\circ} \mathrm{C}$, relative air humidity $48 \% \pm 5 \%$ ). Concentrations of PM fractions were calculated by dividing each fraction's mass by the volume of air, from which it was collected. Dust samples were kept in a refrigerator in tight and lightproof containers until the analysis.

Thirteen samples were fixed for chromatography analysis - for each fraction, a collective sample from 14 weeks was prepared. Samples were placed in ROTH extraction containers. For the extraction, $50 \mathrm{~cm}^{3}$ of deionized water was added to each container and the containers were tightly capped to prevent leaking during the extraction. Extracts were then placed in an ultrasonic

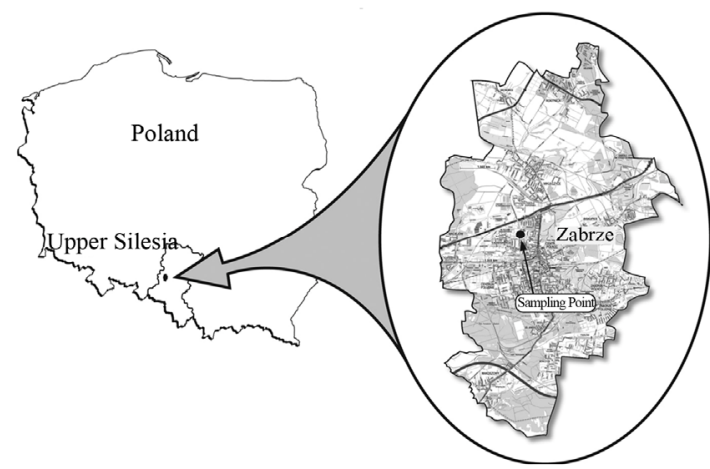

Figure 1. Location of the sampling point. bath (60 min), at a temperature not exceeding $15^{\circ} \mathrm{C}$. Then, the extraction containers were placed in a vortex mixer and shaken overnight at about $18^{\circ} \mathrm{C}$ and 60 cycles per minute. Extracts were then filtered through a CRONUS microporous filter with a PES membrane with a porosity of 0.2 microns.

The ion content in the extracts was determined using Metrohm ion chromatograph (Metrohm Herisau AG, Switzerland), equipped with 818 IC Pump, 819 IC Detector, 837 IC Eluent Degasser, 830 IC Interface, 820 IC Separation Center, Metrodata 2.3 programme). The method was previously validated on the basis of certified reference material (CRM Fluka products nos. 89316 and 89886 , the standard recovery ranged in $92 \%-109 \%$ ). Detection limits were at the level of: $0.02 \mathrm{mg} \cdot 1^{-1}$ for $\mathrm{NH}_{4}^{+}, 0.05 \mathrm{mg} \cdot l^{-1}$ for $\mathrm{Cl}^{-}, \mathrm{SO}_{4}^{2-}$ and $\mathrm{K}^{+}, 0.07 \mathrm{mg} \cdot l^{-1}$ for $\mathrm{NO}_{3}^{-}$and $\mathrm{Na}^{+}, 0.12 \mathrm{mg} \cdot \mathrm{l}^{-1}$ for $\mathrm{Ca}^{2+}$ and $\mathrm{Mg}^{2+}$.

\section{Results and Discussion}

PM-related $\mathrm{Cl}^{-}, \mathrm{NO}_{3}^{-}, \mathrm{SO}_{4}^{2-}, \mathrm{Na}^{+}, \mathrm{NH}_{4}^{+}, \mathrm{K}^{+}, \mathrm{Ca}^{2+}$, $\mathrm{Mg}^{2+}$ concentrations from Zabrze, were compared with concentrations of these ions from various sites in Europe (Table 1). The concentration of the $\mathrm{PM}_{1}$-related ion was calculated by summing its concentrations in following fractions: $0.03-0.06 \mu \mathrm{m}, 0.06-0.108 \mu \mathrm{m}, 0.108-0.17$ $\mu \mathrm{m}, 0.17-0.26 \mu \mathrm{m}, 0.26-0.40 \mu \mathrm{m}, 0.40-0.65 \mu \mathrm{m}$ and $0.65-1.0 \mu \mathrm{m}$. In the case of ions associated with $\mathrm{PM}_{2.5}$, additionally concentrations from fractions: $1.0-1.6 \mu \mathrm{m}$ and 1.6 - $2.5 \mu \mathrm{m}$ were included and in case of $\mathrm{PM}_{10}$, besides previously mentioned, ion concentrations of 2.5 $4.4 \mu \mathrm{m} ; 4.4-6.8 \mu \mathrm{m}$ and $6.8-10.0 \mu \mathrm{m}$ range were summed.

Most of ions' concentrations in Zabrze were comparable to concentrations noted between 1998-2008 in Europe. For example, concentration of sulfates in particulate matter in Zabrze, was comparable to the concentration recorded at two sites in Switzerland, suburban station in Menen (Belgium) and urban background station in Helsinki (Finland). Generally, higher concentrations than in Zabrze are listed in Asian countries [13,30, 31]. Concentration of $\mathrm{Cl}^{-}$associated with fine dust in Zabrze was extraordinarily high comparing to values recorded in other parts of Europe and similar to concentrations of chlorine in Menen and Melpitz, recorded in these cities during the winter season (Table 1).

Sulfates, nitrates and ammonia associated with $\mathrm{PM}_{1}$, $\mathrm{PM}_{2.5}$ and $\mathrm{PM}_{10}$, had the highest concentration of the eight analyzed ions in Zabrze (Tables 1 and 2). Average mass shares of $\mathrm{SO}_{4}^{2-}$ and $\mathrm{NO}_{3}^{-}$in the $\mathrm{PM}_{2.5}$, are about $80 \%$ of the total mass (the sum of the masses in all 13 fractions) of sulfates and nitrates, and the average mass share of $\mathrm{NH}_{4}^{+}$is even up to $98 \%$ of the total mass of ammonia. More than $60 \%$ of sulfates and nitrates mass were related to particles with an aerodynamic diameter 
Table 2. Ambient concentrations of PM $\left(\mu \mathrm{g} \cdot \mathrm{m}^{-3}\right)$ and PM-related ions $\left(\mathrm{ng} \cdot \mathrm{m}^{-3}\right)$ from 13 original DLPI fractions of PM at the urban background site.

\begin{tabular}{cccccccccccc}
\hline Fraction & $\mathrm{PM}$ & $\mathrm{Cl}$ & $\mathrm{NO}_{3}^{-}$ & $\mathrm{SO}_{4}^{2-}$ & $\mathrm{Na}^{+}$ & $\mathrm{NH}_{4}^{+}$ & $\mathrm{K}^{+}$ & $\mathrm{Ca}^{2+}$ & $\mathrm{Mg}^{2+}$ \\
\hline $1 \mathrm{a})$ & 0.34 & 19.89 & 20.34 & 33.97 & 5.14 & 28.70 & 1.66 & 28.74 & 3.04 \\
2 & 0.52 & 22.59 & 17.52 & 44.97 & 7.46 & 22.63 & 7.83 & 11.38 & 4.25 \\
3 & 1.09 & 29.27 & 14.34 & 39.30 & 13.00 & 18.36 & 12.35 & 17.23 & 4.81 \\
4 & 3.05 & 71.35 & 35.52 & 123.07 & 20.16 & 54.52 & 25.28 & 22.76 & 5.59 \\
5 & 5.15 & 103.79 & 89.70 & 221.89 & 44.91 & 199.32 & 46.04 & 22.72 & 4.46 \\
6 & 7.76 & 171.91 & 275.77 & 445.88 & 35.28 & 267.35 & 43.16 & 18.62 & 7.02 \\
7 & 7.65 & 148.60 & 261.54 & 374.47 & 31.08 & 184.05 & 26.25 & 24.96 & 6.46 \\
8 & 5.04 & 78.80 & 85.48 & 245.70 & 28.25 & 169.68 & 12.74 & 29.35 & 7.16 \\
9 & 2.75 & 38.30 & 80.20 & 176.48 & 34.49 & 11.81 & 8.22 & 34.62 & 8.66 \\
10 & 2.35 & 45.77 & 88.84 & 111.14 & 26.84 & 2.28 & 4.46 & 40.90 & 9.56 \\
11 & 1.56 & 27.52 & 51.63 & 67.24 & 14.19 & 1.00 & 2.67 & 40.68 & 8.00 \\
12 & 1.28 & 16.77 & 25.46 & 43.02 & 12.65 & 2.39 & $b l d \mathrm{~b})$ & 52.82 & 10.01 \\
13 & 1.54 & 29.30 & 44.16 & 97.43 & 8.06 & 1.37 & 2.67 & 35.55 & 6.16 \\
\hline
\end{tabular}

a. $1-0.03-0.06 \mu \mathrm{m} ; 2-0.06-0.108 \mu \mathrm{m} ; 3-0.108-0.17 \mu \mathrm{m} ; 4-0.17-0.26 \mu \mathrm{m} ; 5-0.26-0.40 \mu \mathrm{m} ; 6-0.40-0.65 \mu \mathrm{m} ; 7-0.65-1.0 \mu \mathrm{m} ; 8-1.0-1.6 \mu \mathrm{m}$; 9-1.6 - $2.5 \mu \mathrm{m} ; 10-2.5-4.4 \mu \mathrm{m} ; 11-4.4-6.8 \mu \mathrm{m} ; 12-6.8-10.0 \mu \mathrm{m} ; 13 \longrightarrow 10.0 \mu \mathrm{m}$; b. below limit of detection.

$\leq 1 \mu \mathrm{m}$. As to $\mathrm{NH}_{4}^{+}$, it was close to $90 \%$. $\mathrm{SO}_{4}^{2-}, \mathrm{NO}_{3}^{-}$ and $\mathrm{NH}_{4}^{+}$concentrations were highest in the range of $0.26-1 \mu \mathrm{m}$. Very similar, bimodal mass size distribution of $\mathrm{SO}_{4}^{2-}$ and $\mathrm{NO}_{3}^{-}$, with a maximum occurring between 0.4 - $1 \mu \mathrm{m}$ (Figure 2(a)), means that these ions are parts of the same compounds in the dust. The main mechanism of their formation are presumably the transformation processes of PM gaseous precursors occurring in the atmosphere. PM-related $\mathrm{NH}_{4}^{+}$had multimodal mass size distribution, with a one maximum occurring in the range of $0.4-1 \mu \mathrm{m}$ and two maxima between $1.6-10$ $\mu \mathrm{m}$ (Figure 2(b)).

On the areas where sea spray or sea water evaporation (marine aerosols) and road salt are main sources of sodium and chloride, ambient concentrations of $\mathrm{Na}^{+}$and $\mathrm{Cl}^{-}$related to $\mathrm{PM}_{2.5-10}$ (coarse dust, ambient particles with aerodynamic diameters exceeding 2.5 and not greater than $10 \mu \mathrm{m}$ ) are generally higher than the concentrations of $\mathrm{PM}_{1-}$ and $\mathrm{PM}_{2.5}$-related $\mathrm{Na}^{+}$and $\mathrm{Cl}^{-}$(Table 1). It is clear that in Zabrze, $\mathrm{Na}^{+}$and $\mathrm{Cl}^{-}$are related mostly with fine dust particles [26,32]. $\mathrm{PM}_{2.5}$-related $\mathrm{Na}^{+}$ and $\mathrm{Cl}^{-}$were respectively 80 and $85 \%$ of their total concentration in the air of Zabrze. The highest concentrations of PM- related $\mathrm{Na}^{+}$and $\mathrm{Cl}^{-}$, occurred in similar particle sizes range, as in the case of highest $\mathrm{SO}_{4}^{2-}$, $\mathrm{NO}_{3}^{-}$and $\mathrm{NH}_{4}^{+}$concentrations (Table 2). Both, $\mathrm{Na}^{+}$ and $\mathrm{Cl}^{-}$, were characterized by unimodal mass size distribution and its maximum occurred in the range of $0.4-1$ $\mu \mathrm{m}$ (Figures 2(a) and (b)). This indicates the anthropogenic origin of these ions (combustion processes). It is most likely that $\mathrm{Na}^{+}$and $\mathrm{Cl}^{-}$, occur in the dust mainly as a sodium chloride.

The concentration of $\mathrm{K}^{+}, \mathrm{Mg}^{2+}$ and $\mathrm{Ca}^{2+}$ associated with each of 13 fractions, did not exceed $53 \mathrm{ng} \cdot \mathrm{m}^{-3}$ (Table 1). Masses of these cations were distributed differently among PM fractions. More than $95 \%$ of the total mass of $\mathrm{K}^{+}$was concentrated in the $\mathrm{PM}_{2.5}$, over $25 \%$ of which were $\mathrm{PM}_{0.26-0.4}$ and $\mathrm{PM}_{0.4-0.65}$. Distribution of $\mathrm{Ca}^{2+}$ and $\mathrm{Mg}^{2+}$ masses among 13 fractions was more variable, although the share of $\mathrm{PM}_{2.5-10}$-related ions' mass, was much bigger than their contribution in the fine dust particles amount, and was more than $50 \%$ of total mass of these ions in the Zabrze air.

Potassium and calcium were characterized by unimodal mass distribution with a maximum - as in the case of $\mathrm{SO}_{4}^{2-} \quad \mathrm{NO}_{3}^{-}, \mathrm{Na}^{+}$and $\mathrm{Cl}^{-}$- in the range of $0.26-0.65$ $\mu \mathrm{m}$ (Figure 1(b)), whereas magnesium was determined with multimodal size mass distribution, without clearly dominant maximum. Highest potassium concentrations occurred for particles in the range of $0.17-1 \mu \mathrm{m}$ (Table 2). However, higher $\mathrm{Mg}^{2+}$ and $\mathrm{Ca}^{2+}$ concentrations occurred for particles with an aerodynamic diameter larger than $2.5 \mu \mathrm{m}$. Therefore, it seems that $\mathrm{K}^{+}$and $\mathrm{Ca}^{2+}$ may be present in the compounds with $\mathrm{SO}_{4}^{2-}, \mathrm{NO}_{3}^{-}, \mathrm{Na}^{+}$and $\mathrm{Cl}^{-}$ions, and their most probable source in Zabrze air are combustion processes. Relatively high proportion of $\mathrm{Mg}^{2+}$ in the coarse fraction of particulate matter, proves that mechanical processes, including re-suspension of the soil and road dust could have had an influence on these ions concentration levels.

To assess the neutralizing capacity of occurring simultaneously in the air sulfates and nitrates by ammo- 
nium ion, neutralizing ratio (NR) was calculated for each fraction of particulate matter. $\mathrm{NR}$ is the ratio of $\mathrm{NH}_{4}^{+}$ concentration (in normal equivalent, neq $\cdot \mathrm{m}^{-3}$ ) and the sum of $\mathrm{NO}_{3}^{-}$and $\mathrm{SO}_{4}^{2-}$ concentrations (in neq $\cdot \mathrm{m}^{-3}$ )Table 3.

For particles not greater than $1.6 \mu \mathrm{m}$, NR values ranged from $\approx 1\left(\mathrm{PM}_{0.65-1}, \mathrm{PM}_{0.17-0.26}, \mathrm{PM}_{0.108-0.17}\right.$ and $\left.\mathrm{PM}_{0.06-0.108}\right)$ to $1.82\left(\mathrm{PM}_{0.26-0.4}\right)$. It means that the amount of $\mathrm{NH}_{4}^{+}$related to these dust fractions, was sufficient to neutralize sulfuric and nitric acid completely. This result also proves that ambient fine dust $\left(\mathrm{PM}_{1.6}\right)$ in Zabrze is alkaline (NR $\geq 1)$.

Stoichiometric ratio for $\left(\mathrm{NH}_{4}\right)_{2} \mathrm{SO}_{4}$ of $\mathrm{SO}_{4}^{2-} / \mathrm{NH}_{4}^{+}$is 2.67. In all fractions of particles $\leq 1.6 \mu \mathrm{m}$, the ratio of $\mathrm{SO}_{4}^{2-}$ and $\mathrm{NH}_{4}^{+}$(in neq $\cdot \mathrm{m}^{-3}$ ) is much lower than 2.67. It confirms the previous deduction, that $\mathrm{PM}_{1.6}$-related
$\mathrm{NH}_{4}^{+}$in Zabrze occurred in a greater amount than needed to react with the $\mathrm{PM}_{1.6}$-related $\mathrm{SO}_{4}^{2-}$ completely. Also the condition $\mathrm{NH}_{4}^{+}>\mathrm{SO}_{4}^{2-}$ (in neq $\cdot \mathrm{m}^{-3}$ ) is satisfied. Therefore, the concentration of $\left(\mathrm{NH}_{4}\right)_{2} \mathrm{SO}_{4}$ may be estimated from the formula:

$$
\left[\left(\mathrm{NH}_{4}\right)_{2} \mathrm{SO}_{4}\right]=1.38\left[\mathrm{SO}_{4}^{2-}\right]
$$

The concentration of $\left(\mathrm{NH}_{4}\right)_{2} \mathrm{SO}_{4}$ associated with particles $\leq 1.6 \mu \mathrm{m}$, fit within the limits of $615.31 \mathrm{ng} \cdot \mathrm{m}^{-3}$ $\left(\mathrm{PM}_{0.4-0.65}\right)$ to $46.88 \mathrm{ng} \cdot \mathrm{m}^{-3}$ for $\mathrm{PM}_{0.03-0.06}$. The amount (concentration) of $\mathrm{NH}_{4}^{+}$, remaining after reaction with $\mathrm{SO}_{4}^{2-}$ (ammonium ion excess $\left[\right.$ ex- $\left.\mathrm{NH}_{4}^{+}\right]$) and ammonium nitrate concentration associated with each fractions of particles $\leq 1.6 \mu \mathrm{m}$, was calculated from the following formulas:

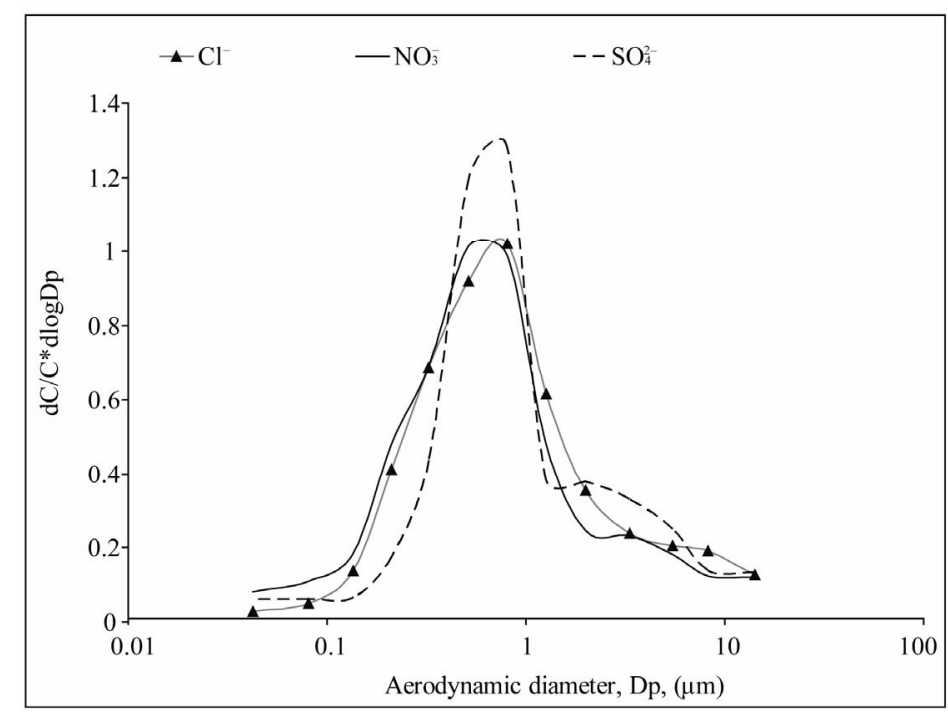

(a)

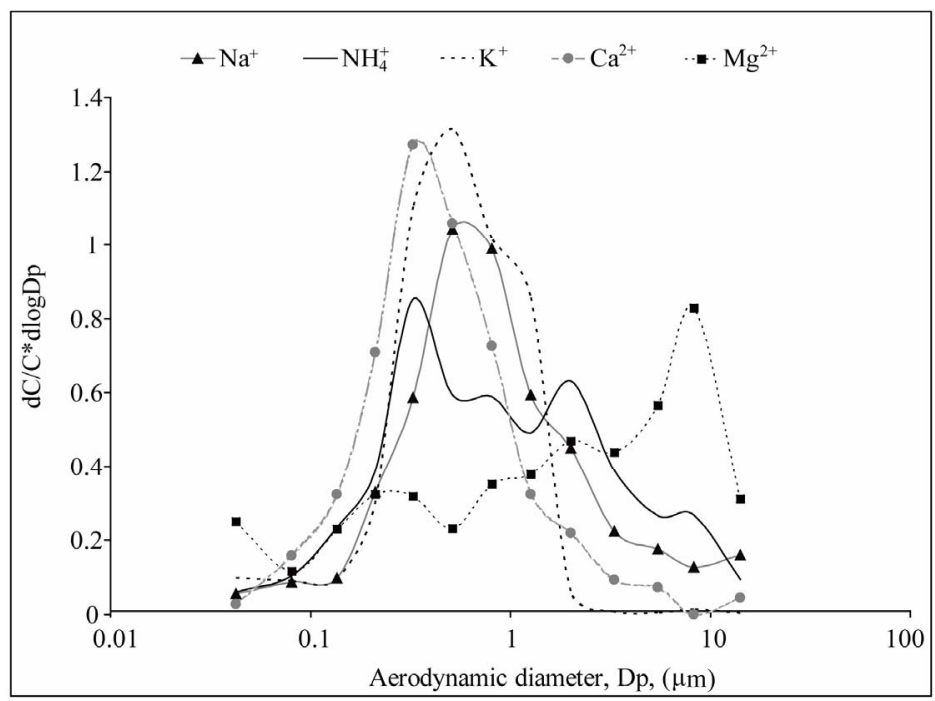

(b)

Figure 2. Mass size distribution of PM-related ions in Zabrze, Poland. 
Table 3. Proportions of the ionic equivalent concentrations and probable composition of secondary inorganic aerosol in 13 original DLPI fractions of PM at the urban background site in Zabrze, Poland.

\begin{tabular}{|c|c|c|c|c|c|c|c|c|c|c|c|c|c|}
\hline 冚 & 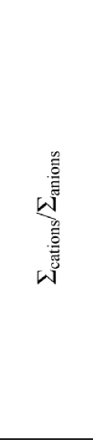 & 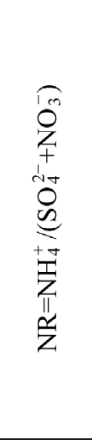 & $\underset{\substack{1 \\
\text { d+ } \\
0 \\
\infty}}{\mathbb{Z}}$ & 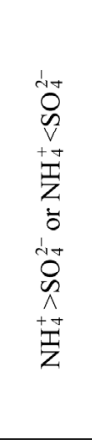 & 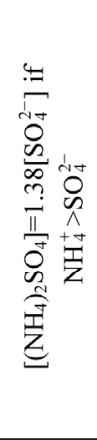 & 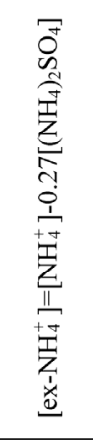 & 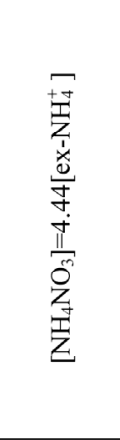 & 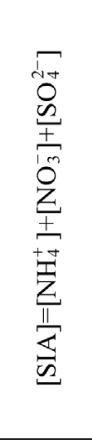 & 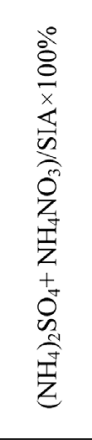 & 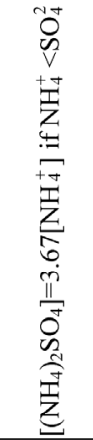 & 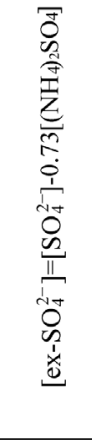 & 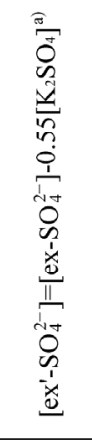 & 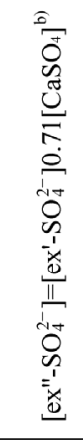 \\
\hline & neq. $\mathrm{m}^{-3}$ & neq. $\mathrm{m}^{-3}$ & neq. $\mathrm{m}^{-3}$ & neq. $\mathrm{m}^{-3}$ & $n g \cdot m^{-3}$ & $\mathrm{ng} \cdot \mathrm{m}^{-3}$ & $\mathrm{ng} \cdot \mathrm{m}^{-3}$ & ng. $\mathrm{m}^{-3}$ & $\%$ & $n g \cdot m^{-3}$ & ng. $m^{-3}$ & $\mathrm{ng} \cdot \mathrm{m}^{-3}$ & ng.m $\mathrm{m}^{-3}$ \\
\hline$>10$ & 0.76 & 0.03 & 26.76 & $<$ & - & - & - & - & - & 5.01 & 93.79 & 90.5 & -0.76 \\
\hline $4.4-6.8$ & 1.11 & 0.02 & 25.21 & $<$ & - & - & - & - & - & 3.67 & 64.57 & 61.29 & -0.52 \\
\hline $2.5-4.4$ & 0.83 & 0.03 & 18.28 & $<$ & - & - & - & - & - & 8.37 & 105.05 & 99.56 & -0.85 \\
\hline $1.6-2.5$ & 0.79 & 0.13 & 5.6 & $<$ & - & - & - & - & - & 43.34 & 144.95 & 134.84 & -1.18 \\
\hline $1-1.6$ & 1.49 & 1.45 & 0.54 & $>$ & 339.06 & 169.68 & 753.38 & 500.86 & 218.11 & - & - & - & - \\
\hline $0.65-1$ & 0.92 & 0.89 & 0.76 & $>$ & 516.76 & 44.52 & 197.69 & 820.06 & 87.12 & - & - & - & - \\
\hline $0.4-0.65$ & 1.02 & 1.08 & 0.63 & $>$ & 615.31 & 101.22 & 449.4 & 988.99 & 107.66 & - & - & - & - \\
\hline $0.26-0.4$ & 1.75 & 1.82 & 0.42 & $>$ & 306.2 & 116.64 & 517.91 & 510.91 & 161.3 & - & - & - & - \\
\hline $0.17-0.26$ & 1.19 & 0.97 & 0.85 & $>$ & 169.83 & 54.52 & 242.07 & 213.1 & 193.29 & - & - & - & - \\
\hline $0.108-0.17$ & 1.68 & 0.97 & 0.8 & $>$ & 54.23 & 18.36 & 81.52 & 72 & 188.55 & - & - & - & - \\
\hline
\end{tabular}

${ }^{\mathrm{a}}\left[\mathrm{K}_{2} \mathrm{SO}_{4}\right]=1.8\left[\mathrm{ex}-\mathrm{SO}_{4}^{2-}\right] ;{ }^{\mathrm{b}}\left[\mathrm{CaSO}_{4}\right]=1.42\left[\mathrm{ex}^{\prime}-\mathrm{SO}_{4}^{2-}\right]$.

$$
\begin{gathered}
{\left[\text { ex- } \mathrm{NH}_{4}^{+}\right]=\left[\mathrm{NH}_{4}^{+}\right]-0.27\left[\left(\mathrm{NH}_{4}\right)_{2} \mathrm{SO}_{4}\right]} \\
{\left[\mathrm{NH}_{4} \mathrm{NO}_{3}\right]=4.44\left[\mathrm{ex}-\mathrm{NH}_{4}^{+}\right]}
\end{gathered}
$$

$\mathrm{NH}_{4} \mathrm{NO}_{3}$ concentration ranged from $753.38 \mathrm{ng} \cdot \mathrm{m}^{-3}$ (for $\mathrm{PM}_{1-1.6}$ ) to $81.52 \mathrm{ng} \cdot \mathrm{m}^{-3}$ (for $\mathrm{PM}_{0.108-0.17}$ ).

$\left(\mathrm{NH}_{4}\right)_{2} \mathrm{SO}_{4}$ and $\mathrm{NH}_{4} \mathrm{NO}_{3}$ concentrations sum share, in a total SIA concentration

$\left([\mathrm{SIA}]=\left[\mathrm{NH}_{4}^{+}\right]+\left[\mathrm{NO}_{3}^{-}\right]+\left[\mathrm{SO}_{4}^{2-}\right]\right)$ for fractions of particles $\leq 1.6 \mu \mathrm{m}$, is shown in Table 3. For the fraction with $\left(\left(\mathrm{NH}_{4}\right)_{2} \mathrm{SO}_{4}+\mathrm{NH}_{4} \mathrm{NO}_{3}\right) / \mathrm{SIA}$ value exceeding 1 , the share is overestimated. Still, stoichiometric calculations that have been carried out, show that these two compounds constitute the entirety of SIA in ambient particles not greater than $1.6 \mu \mathrm{m}$. The most probable distribution of $\left(\mathrm{NH}_{4}\right)_{2} \mathrm{SO}_{4}$ and $\mathrm{NH}_{4} \mathrm{NO}_{3}$ concentrations between the sum of these compounds concentrations were obtained for $\mathrm{PM}_{0.65-1}$ and $\mathrm{PM}_{0.4-0.65}$, where the share of $\left(\left(\mathrm{NH}_{4}\right)_{2} \mathrm{SO}_{4}\right.$ $+\mathrm{NH}_{4} \mathrm{NO}_{3}$ ) in the SIA did not exceed $100 \%$. There are also these two fractions, in which the predominant part in the SIA takes ammonium sulfate, while the concentra- tions of these two dust fractions in the air are the highest of all 13 (Table 2).

NR for particles greater than $1.6 \mu \mathrm{m}$, was much smaller than 1 (Table 3). However, it doesn't mean that ions associated with these particles are not fully neutralized. The concentration sum ratio of anions to cations $\left(\Sigma_{\text {cations }} / \Sigma_{\text {anions }}\right.$, in neq $\left.\cdot \mathrm{m}^{-3}\right)$ is in the range of 1 , for all frac- tions.

In all fractions of particles greater than $1.6 \mu \mathrm{m}$, the concentration ratios of $\mathrm{SO}_{4}^{2-}$ and $\mathrm{NH}_{4}^{+}$(in neq. ${ }^{-3}$ ) is considerably higher than 2.67. Also the relation $\mathrm{NH}_{4}^{+}<\mathrm{SO}_{4}^{2-}$ is satisfied (concentrations in neq $\cdot \mathrm{m}^{-3}$ ). It means that in these $\mathrm{PM}$ fractions, $\mathrm{NH}_{4}^{+}$could neutralize some part of $\mathrm{SO}_{4}^{2-}$, forming $\left(\mathrm{NH}_{4}\right)_{2} \mathrm{SO}_{4}$ but there was not enough of $\mathrm{NH}_{4}^{+}$to react the whole $\mathrm{SO}_{4}^{2-}$. Thus, there was not enough of $\mathrm{NH}_{4}^{+}$to form ammonium nitrate. Therefore, the $\left(\mathrm{NH}_{4}\right)_{2} \mathrm{SO}_{4}$ concentration for particles greater than $1.6 \mu \mathrm{m}$, can be calculated from the for mula:

$$
\left[\left(\mathrm{NH}_{4}\right)_{2} \mathrm{SO}_{4}\right]=3.67\left[\mathrm{NH}_{4}^{+}\right]
$$


The concentration of $\left(\mathrm{NH}_{4}\right)_{2} \mathrm{SO}_{4}$ associated with particles greater than $1.6 \mu \mathrm{m}$, ranged from $3.67 \mathrm{ng} \cdot \mathrm{m}^{-3}$ $\left(\mathrm{PM}_{4.4-6.8}\right)$ to $43.34 \mathrm{ng} \cdot \mathrm{m}^{-3}$ for $\mathrm{PM}_{1.6-2.5}$.

It is impossible to determine precisely concentrations of all compounds constituting the secondary inorganic aerosol in Zabrze, still, estimating on the basis of stoichiometric relations. However, it can be shown that the amount of $\mathrm{SO}_{4}^{2-}$ in the particles greater than $1.6 \mu \mathrm{m}$ is enough to react the whole $\mathrm{NH}_{4}^{+}$.

The rest of the $\mathrm{SO}_{4}^{2-}$ (sulfate ion excess $\left[\right.$ ex- $\left.\mathrm{SO}_{4}^{2-}\right]$ ) could react i.a. with potassium and calcium ions, forming $\mathrm{K}_{2} \mathrm{SO}_{4}$ and $\mathrm{CaSO}_{4}$. This would prove specific, similar to $\mathrm{SO}_{4}^{2-}$, mass size distributions of $\mathrm{K}^{+}, \mathrm{Ca}^{2+}$ (Figures 2(a) and (b)). The concentration of the rest of $\mathrm{SO}_{4}^{2-}$, that remained after:

- reaction with $\mathrm{NH}_{4}^{+}$forming $\left(\mathrm{NH}_{4}\right)_{2} \mathrm{SO}_{4}$; $\left(\left[\mathrm{ex}^{-} \mathrm{SO}_{4}^{2-}\right]\right)$,

- reaction with $\mathrm{NH}_{4}^{+}$forming $\left(\mathrm{NH}_{4}\right)_{2} \mathrm{SO}_{4}$ and $\mathrm{K}^{+}$ forming $\mathrm{K}_{2} \mathrm{SO}_{4}$; $\left(\left[\mathrm{ex}^{\prime}-\mathrm{SO}_{4}^{2-}\right]\right)$,

- reaction with $\mathrm{NH}_{4}^{+}$forming $\left(\mathrm{NH}_{4}\right)_{2} \mathrm{SO}_{4}, \mathrm{~K}^{+}$forming $\mathrm{K}_{2} \mathrm{SO}_{4}$ and $\mathrm{Ca}^{2+}$ forming $\mathrm{CaSO}_{4}$; ([ex"-- $\left.\mathrm{SO}_{4}^{2-}\right]$ ) can be calculated (in $\mathrm{PM}_{1.6-2.5}, \mathrm{PM}_{2.5-4.4}, \mathrm{PM}_{4.4-6.8}$, $\mathrm{PM}_{6.8-10}, \mathrm{PM}_{>10}$ ) from the following formula:

$$
\begin{gathered}
{\left[\mathrm{ex}^{-\mathrm{SO}_{4}^{2-}}\right]=\left[\mathrm{SO}_{4}^{2-}\right]-0.73\left[\left(\mathrm{NH}_{4}\right)_{2} \mathrm{SO}_{4}\right]} \\
{\left[\mathrm{ex}^{\prime}-\mathrm{SO}_{4}^{2-}\right]=\left[\mathrm{ex}^{-\mathrm{SO}_{4}^{2-}}\right]-0.55\left[\mathrm{~K}_{2} \mathrm{SO}_{4}\right]} \\
{\left[\mathrm{ex}^{\prime}-\mathrm{SO}_{4}^{2-}\right]=\left[\mathrm{ex}^{\prime}-\mathrm{SO}_{4}^{2-}\right]-0.71\left[\mathrm{CaSO}_{4}\right]}
\end{gathered}
$$

Using values listed in Table 3, it can be concluded that for $\mathrm{PM}_{>1.6}$, there was not enough sulfate ion to complete reaction of calcium ions $\left(\left[\mathrm{ex}^{\mathrm{N}}-\mathrm{SO}_{4}^{2-}\right]<0\right)$.

Therefore, it can be concluded, that the secondary inorganic aerosol in Zabrze, in the case of compounds occuring in particles greater than $1.6 \mu \mathrm{m}$, is mainly composed of ammonium sulfate, potassium sulfate and calcium sulfate. Certainly, there are also nitrates in these particles, however, in contrast to particles not greater than $1.6 \mu \mathrm{m}$, there is no ammonium nitrate but probably $\mathrm{NaNO}_{3}$ and/or $\mathrm{Ca}\left(\mathrm{NO}_{3}\right)_{2}$.

\section{Conclusions}

Most of ions' concentrations in Zabrze were comparable to concentrations presented in the literature. Generally, higher concentrations than in Zabrze are listed in Asian countries, this concerns particularly to $\mathrm{SO}_{4}^{2-}, \mathrm{NH}_{4}^{+}, \mathrm{K}^{+}$, $\mathrm{Mg}^{2+}$ and $\mathrm{Ca}^{2+}$. Concentration of $\mathrm{Cl}^{-}$associated with fine dust in Zabrze was extraordinarily high, comparing to values recorded in other parts of the world.

Sulfates, nitrates and ammonium had the highest concentration of the eight analyzed ions in Zabrze. More than $60 \%$ of $\mathrm{SO}_{4}^{2-}$ and $\mathrm{NO}_{3}^{-}$and $90 \%$ of $\mathrm{NH}_{4}^{+}$mass, was concentrated in particles with an aerodynamic diameter $\leq 1$ micron. $\mathrm{Na}^{+}$and $\mathrm{Cl}^{-}$were also mostly associated with fine dust particles. Ions mentioned above, as well as $\mathrm{K}^{+}$and $\mathrm{Ca}^{2+}$, had similar mass size distributions, and generally, maxima of these distributions were in the same particle size ranges. This indicates the anthropogenic origin of seven of eight analyzed ions (combustion processes), associated with dust in Zabrze.

Relatively high proportion of $\mathrm{Mg}^{2+}$ in the coarse fraction of particulate matter, proves that mechanical processes, including re-suspension of the soil and road dust could have had an influence on $\mathrm{Mg}^{2+}$ concentration in the air.

In particles not greater than $1.6 \mu \mathrm{m}$, the amount of ammonium ion is sufficient to neutralize sulfuric and nitric acid, therefore, in dust precursors gas conversions, ammonium sulfate and nitrate are formed. In fractions of particles greater than $1.6 \mu \mathrm{m}$, the amount of ammonium ion is not sufficient to neutralize the nitric acid. Therefore, in these fractions, inorganic aerosol is composed of ammonium sulfate and other compounds, including $\mathrm{K}_{2} \mathrm{SO}_{4}$ and $\mathrm{CaSO}_{4}$, and also $\mathrm{NaNO}_{3}$ and/or $\mathrm{Ca}\left(\mathrm{NO}_{3}\right)_{2}$.

\section{Acknowledgements}

The work was partially supported by grant No. N N523 564038 from the Polish Ministry of Science and Higher Education.

\section{REFERENCES}

[1] J. Schwartz, "Air Pollution and Daily Mortality: A Review and Meta-Analysis," Environmental Research, Vol. 64, No. 1, 1994, pp. 36-52. doi:10.1006/enrs.1994.1005

[2] K. R. Spurny, "Chemical Mixtures in Atmospheric Aerosols and Their Correlation to Lung Diseases and Lung Cancer Occurrence in the General Population," Toxicology Letters, Vol. 88, No. 1-3, 1996, pp. 271-277. doi:10.1016/0378-4274(96)03749-6

[3] C. A. Pope and D. W. Dockery, "Health Effects of Fine Particulate Air Pollution: Lines that Connect," Journal of the Air \& Waste Management Association, Vol. 56, No. 6, 2006, pp. 709-742. doi:10.1080/10473289.2006.10464485

[4] G. Majewski and W. Przewoźniczuk, "Study of Particulate Matter Pollution in Warsaw Area," Polish Journal of Environmental Studies, Vol. 18, No 2, 2009, pp. 293-300.

[5] P. Huszar, K. Juda-Rezler, T. Halenka, H. Chervenkov, D. Syrakov, B. C. Krueger, P. Zanis, D. Melas, E. Katragkou, M. Reizer, W. Trapp and M. Belda, "Effects of Climate Change on Ozone and Particulate Matter over Central and Eastern Europe," Climate Research, Vol. 50, No. 1, 2011. pp. 51-68. doi:10.3354/cr01036

[6] M. Kowalska, M. Skrzypek, F. Danso and J. KaszniaKocot, "Relative Risk of Total and Cardiovascular Mor- 
tality in the Eldery as Related to Short-Term Increases of $\mathrm{PM}_{2.5}$ Concentrations in Ambient Air," Polish Journal of Environmental Studies, Vol. 21, No. 5, 2012, pp. 12791285.

[7] E. López-Villarrubia, C. Iñiguez, N. Peral, M. D. García and F. Ballester, "Characterizing Mortality Effects of Particulate Matter Size Fractions in the Two Capital Cities of the Canary Islands," Environmental Research, Vol. 112, 2012, pp. 129-138. doi:10.1016/j.envres.2011.10.005

[8] M. Tainio, K. Juda-Rezler, M. Reizer, A. Warchałowski, W. Trapp and K. Skotak, "Future Climate and Adverse Health Effects Caused by Fine Particulate Matter Air Pollution: Case Study for Poland," Regional Environmental Change, 2012 (in Press).

[9] K. T. Whitby, "The Physical Characteristics of Sulfur Aerosol," Atmospheric Environment, Vol. 12, No. 1-3, 1978, pp. 135-139. doi:10.1016/0004-6981(78)90196-8

[10] D. Grosjean and J. H. Seinfeld, "Parametrization of the Formation Potential of Secondary Organic Aerosols," Atmospheric Environment, Vol. 23, No. 8, 1989, pp. 17331147. doi:10.1016/0004-6981(89)90058-9

[11] E. R. Whitby and P. H. McMurry, "Modal Aerosol Dynamics Modeling," Aerosol Science and Technology, Vol. 27, No. 6, 1997, pp. 673-688. doi:10.1080/02786829708965504

[12] W. C. Hinds, "Aerosol Technology. Properties, Behavior, and Measurement of Airborne Particles," 2nd Edition, John Wiley \& Sons, Inc., New York, 1998.

[13] K. Klejnowski, J. S. Pastuszka, W. Rogula-Kozłowska, E. Talik and A. Krasa, "Mass Size Distribution and Chemical Composition of the Surface Layer of Summer and Winter Airborne Particles in Zabrze, Poland," Bulletin of Environmental Contamination and Toxicology, Vol. 88, No. 2, 2012, pp. 255-259. doi:10.1007/s00128-011-0452-3

[14] B. Ostro, W. Y. Feng, R. Broadwin, S. Green and M. Lipsett, "The Effects of Components of Fine Particulate Air Pollution on Mortality in California: Results from CALFINE," Environmental Health Perspectives, Vol. 115, 2007, pp. 13-19. doi:10.1289/ehp.9281

[15] N. Englert, "Fine Particles and Human Health-A Review of Epidemiological Studies," Toxicology Letters, Vol. 149, No. 1-3, 2004, pp. 235-242. doi:10.1016/i.toxlet.2003.12.035

[16] R. Rückerl, A. Schneider, S. Breitner, J. Cyrys and A. Peters, "Health Effects of Particulate Air Pollution: A Review of Epidemiological Evidence," Inhalation Toxicology, Vol. 23, No. 10, 2011, pp. 555-592. doi: $10.3109 / 08958378.2011 .593587$

[17] W. Zhang, T. Lei, Z. Q. Lin, H. S. Zhang, D. F. Yang, Z. G. Xi, J. H. Chen and W. Wang, "Pulmonary Toxicity Study in Rats with $\mathrm{PM}_{10}$ and $\mathrm{PM}_{2.5}$ : Differential Responses Related to Scale and Composition," Atmospheric Environment, Vol. 45, No. 4, 2011, pp. 1034-1041. doi:10.1016/j.atmosenv.2010.10.043

[18] J. H. Seinfeld, "Atmospheric Chemistry of Physics of Air Pollution," Wiley, New York, 1986.

[19] A. Jaecker-Voirol and P. Mirabel, "Heteromolecular Nu- cleation in the Sulphuric Acid-Water System," Atmospheric Environment, Vol. 23, No. 9, 1989, pp. 2053-2057. doi:10.1016/0004-6981(89)90530-1

[20] J. G. Watson, J. C. Chow, F. Lurmann and S. Musarra, "Ammonium Nitrate, Nitric Acid, and Ammonia Equilibrium in Wintertime Phoenix, AZ," Journal of the Air \& Waste Management Association, Vo. 44, No. 4, 1994, pp. 261-268

[21] P. Korhonen, M. Kumala, A. Laaksonen, Y. Viisanen, R. McGraw and J. H. Seinfeld, "Ternary Nucleation of $\mathrm{H}_{2} \mathrm{SO}_{4}, \mathrm{NH}$; and $\mathrm{H}_{2} \mathrm{O}$ in the Atmosphere," Journal of Geophysical Research, Vol. 104, No. D21, 1999, pp. 26349-26353. doi:10.1029/1999JD900784

[22] G. J. Sun, L. Yao, L. Jiao, Y. Shi, Q. Y. Zhang, M. N. Tao, G. R. Shan and Y. He, "Characterizing $\mathrm{PM}_{2.5}$ Pollution of a Subtropical Metropolitan Area in China," Atmospheric and Climate Sciences, Vol. 3, No. 1, 2013, pp. 100-110. doi:10.4236/acs.2013.31012

[23] M. Sillanpää, R. Hillamo, S. Saarikoski, A. Frey, A. Pennanen, U. Makkonen, Z. Spolnik, R. Van Grieken, M. Braniš, B. Brunekreef, M. C. Chalbot, T. Kuhlbusch, J. Sunyer, V. M. Kerminen, M. Kulmala and R. O. Salonen, "Chemical Composition and Mass Closure of Particulate Matter at Six Urban Sites in Europe," Atmospheric Environment, Vol. 40, Suppl. 2, 2006, pp. S212-S223. doi:10.1016/j.atmosenv.2006.01.063

[24] T. Lee, X.-Y. Yu, B. Ayres, S. M. Kreidenweis, W. C. Malm and J. L. Collett Jr., "Observations of Fine and Coarse 5 Particle Nitrate at Several Rural Locations in the United States," Atmospheric Environment, Vol. 42, No. 11, 2008, pp. 2720-2732. doi:10.1016/j.atmosenv.2007.05.016

[25] Y. Zhao and Y. Gao, "Mass Size Distributions of WaterSoluble Inorganic and Organic Ions in Size-Segregated Aerosols over Metropolitan Newark in the US East Coast," Atmospheric Environment, Vol. 42, No. 18, 2008, pp. 40634078. doi:10.1016/j.atmosenv.2008.01.032

[26] W. Rogula-Kozłowska, K. Klejnowski, P. Rogula-Kopiec, B. Mathews and S. Szopa, "A Study on the Seasonal Mass Closure of Ambient Fine and Coarse Dusts in Zabrze, Poland," Bulletin of Environmental Contamination and Toxicology, Vol. 88, No. 5, 2012, pp. 722-729. doi:10.1007/s00128-012-0533-y

[27] Z. Y. Meng and J. H. Seinfeld, "On the Source of the Submicrometer Droplet Mode of Urban and Regional Aerosols," Aerosol Science and Technology, Vol. 20, No. 3, 1994, pp. 253-265. doi:10.1080/02786829408959681

[28] R. F. Pueshel, "Stratospheric Aerosols: Formation, Properties, Effect," Journal of Aerosol Science, Vol. 27, No. 3, 1996, pp. 359-382.

[29] K. Klejnowski, W. Rogula-Kozłowska and A. Krasa, "Structure of Atmospheric Aerosol in Upper Silesia (Poland)-Contribution of $\mathrm{PM}_{2.5}$ to $\mathrm{PM}_{10}$ in Zabrze, Katowice and Częstochowa in 2005-2007," Archives of Environmental Protection, Vol. 35, No. 2, 2009, pp. 3-13

[30] D. K. Deshmukh, Y. I. Tsai, M. K. Deb and P. Zarmpas, "Characteristics and Sources of Water-Soluble Ionic Species Associated with $\mathrm{PM}_{10}$ Particles in the Ambient Air of Central India," Bulletin of Environmental Contamination 
and Toxicology, Vol. 89, No. 5, 2012, pp. 1091-1097. doi:10.1007/s00128-012-0806-5

[31] N. Chuersuwan, S. Nimrat, S. Lekphet and T. Kerdkumrai, "Levels and Major Sources of $\mathrm{PM}_{2.5}$ and $\mathrm{PM}_{10}$ in Bangkok Metropolitan Region," Environment International, Vol. 34, No. 5, 2008, pp. 671-677. doi:10.1016/j.envint.2007.12.018

[32] W. Rogula-Kozłowska and K. Klejnowski, "Submicrometer Aerosol in Rural and Urban Backgrounds in Southern Poland - Primary and Secondary Components of $\mathrm{PM}_{1}$," Bulletin of Environmental Contamination and Toxicology, Vol. 90, No. 1, 2013, pp. 103-109. doi:10.1007/s00128-012-0868-4

[33] C. Hüeglin, R. Gehrig, U. Baltensperger, M. Gysel, C. Monn and H. Vonmont, "Chemical Characterization of $\mathrm{PM}_{2.5}, \mathrm{PM}_{10}$ and Coarse Particles at Urban, Near-City and Rural Sites in Switzerland," Atmospheric Environment, Vol. 39, No. 4, 2005, pp. 637-651. doi:10.1016/j.atmosenv.2004.10.027

[34] D. Temesi, A. Molnár, E. Mészáros, T. Feczkó, A. Gelencsér, G. Kiss and Z. Krivácsy, "Size Resolved Chemical Mass Balance of Aerosol Particles over Rural Hungary," Atmospheric Environment, Vol. 35, No. 25, 2001, pp. 4347-4355. doi:10.1016/S1352-2310(01)00233-3

[35] P. Salvador, B. Artíñano, X. Querol, A. Alastuey and M. Costoya, "Characterisation of Local and External Contributions of Atmospheric Particulate Matter at a Background Coastal Site," Atmospheric Environment, Vol. 41, No. 1, 2007, pp. 1-17. doi:10.1016/j.atmosenv.2006.08.007

[36] M. Viana, X. Querol and A. Alastuey, "Chemical Char- acterisation of PM Episodes in NE Spain," Chemosphere, Vol. 62, No. 6, 2006, pp. 947-956. doi:10.1016/i.chemosphere.2005.05.048

[37] M. Sillnapää, S. Saarikoski, R. Hillamo, A. Pennanen, U. Makkonen, Z. Spolnik, R. Van Grieken, T. Koskentalo and R. O. Salonen, "Chemical Composition, Mass Size Distribution and Source Analysis of Longe-Range Transported Wildfire Smokes in Helsinki," Science of the Total Environment, Vol. 350, No. 1-3, 2005, pp. 119-135. doi:10.1016/j.scitotenv.2005.01.024

[38] K. Ravindra, M. Stranger and R. Van Grieken, "Chemical Characterization and Multivariate Analysis of Atmospheric $\mathrm{PM}_{2.5}$ Particles," Journal of Atmospheric Chemistry, Vol. 59, No. 3, 2008, pp. 199-218. doi:10.1007/s10874-008-9102-5

[39] M. Čačković, V. Vađić, K. Šega and I. Bešlić, "Acidic Anions in $\mathrm{PM}_{10}$ Particle Fraction in Zagreb Air, Croatia," Bulletin of Environmental Contamination and Toxicology, Vol. 83, No. 2, 2009, pp. 188-192. doi:10.1007/s00128-009-9641-8

[40] G. Spindler, E. Brüggemann, T. Gnauk, A. Grüner, K. Müller and H. Herrmann, "A Four-Year Size-Segregated Characterization Study of Particles $\mathrm{PM}_{10}, \mathrm{PM}_{2.5}$ and $\mathrm{PM}_{1}$ Depending on Air Mass Origin at Melpitz," Atmospheric Environment, Vol. 44, No. 2, 2010, pp. 164-173. doi:10.1016/j.atmosenv.2009.10.015

[41] I. Kopanakis, N. Lydakis-Simantiris, E. Katsivela, D. Pentari, P. Zarmpas, N. Mihalopoulos and M. Lazaridis, "Size Distribution and Chemical Composition of Airborne Particles at Akrotiri Research Station, Crete, Greece," Global Nest Journal, Vol. 12, No. 1, 2010, pp. 54-62. 